\title{
ВПЛИВ МЕДИКАМЕНТОЗНОЇ КОРЕКЦІЇ ГІПОТИРЕОЗУ НА СТАН СТРУКТУРНОЇ ОРГАНІЗАЦІЇ ЯЄЧОК ЩУРІВ ПІСЛЯ ТИРЕОЇДЕКТОМІї
}

\begin{abstract}
Резюме. Питання пошуку есрективних підходів до медикаментозної корекції гіпотиреозу і їх морфоорункціональне обґрунтування продовжує залишатися одним із актуальних питань сучасної медичної науки.

Мета дослідження - дати порівняльну морфофункціональну характеристику ефективності застосування монотерапії L-тироксином і його комбінації з тіотриазоліном для корекції посттиреоїдектомічного гіпотиреозу.

Матеріали і методи. Експерименти проведено на статевозрілих білих лабораторних щурах-самцях. Визначали масу яєчок, при оглядовій мікроскопії вивчали морфологічні особливості їх будови, визначили кількість звивистих сім'яних канальців у одному полі зору та наступні морфометричні показники: товщини білкової оболонки, сперматогенного епітелію. Оцінку функціональної активності яєчок проводили шляхом вирахування індексу сперматогенезу, оцінку функціонального стану судин проводили за величиною індексу Вогенворта.

Результати досліджень та їх обговорення. Після тиреоїдектомії у статевих залозах щурів-самців було виявлено значні розлади органного кровообігу, які на ранніх стадіях проявлялися вираженим венозним і помірним артеріальним повнокров'ям з одночасним розвитком інтерстиційного набряку. В подальшому артеріальний відділ органного кровоносного русла реагував зменшенням своєї пропускної здатності за рахунок звуження просвіту дрібних артерій і артеріол, на тлі яких розвивалися і прогресували дистрофічні зміни як у стромі, так і в паренхімі органа. Трофрічні розлади супроводжувалися спустошенням сім'яних канальців унаслідок різкого зменшення у них клітин сперматогенного епітелію, їх фіброзною транссормацією та наступним розростанням сполучної тканини в інтерстиції. Виявлені структурні зміни $є$ наслідком як безпосереднього впливу гіпотиреозу на стан їх структурних компонентів, так і опосередкованого через порушення органного кровотоку. Застосування монотерапії L-тироксином у післяопераційному періоді лише частково попереджає розвиток виявлених морфофункціональних змін.
\end{abstract}

Висновки. Серед досліджених препаратів найбільшу ефективність в умовах експерименту проявило комплексне поєднане застосування L-тироксину з тіотриазоліном.

ключові слова: гіпотиреоз; сперматогенез; кровообіг; дистросрія.

ВСтуп За останні десятиріччя відмічається зростання патології щитоподібної залози зі зниженням її фрункціональної активності. За даними різних досліджень, це призводить до хронічних розладів фуннкцій нервової, серцево-судинної, сечовидільної, статевої, травної та інших систем [1, 2]. Разом з тим, як уже встановлено, замісна терапія, що базується на застосуванні лише L-тироксину, не попереджає морфоорункціональних змін в органах і системах, але лише відтерміновує їх у часі [2-4]. Тому питання пошуків більш ефективних комплексних підходів до медикаментозної корекції гіпотиреозу і їх морфоорункціональне обґрунтування продовжує залишатися одним із актуальних питань сучасної медичної науки $[5,6]$. Одним із таких додаткових засобів може бути препарат "Тіотриазолін”, основним механізмом дії якого $€$ поліпшення синтезу та витрати енергії через АТФ, а також відновлення балансу між вільнорадикальним окисненням і антиоксидантним захистом [7, 8].

Метою дослідження було дати порівняльну морфофрункціональну характеристику ефективності застосування монотерапії L-тироксином і його комбінації з тіотриазоліном для корекції посттиреоїдектомічного гіпотиреозу.

МАТЕРІАЛИ I МЕТОДИ Експерименти проведено на 102 статевозрілих білих лабораторних щурах-самцях із масою тіла 160-180 г. 3 них 12 тварин склали контрольну групу (6 інтактних щурів і 6 щурів, яким під кетаміновим знеболюванням проводили розтин шкіри на шиї як доступ до щитоподібної залози). Іших щурів поділили на 3 експериментальних групи, яким під кетаміновим знеболюванням проводили тиреоїдектомію. 3 них 30 щурам тиреоїдектомію виконували без медикаментозної корекції гіпотиреозу, 30 - $з$ корекцією лише L-тироксином і ще 30 - 3 корекцією L-тироксином у комбінації з тіотриазоліном.
L-тироксин (“Фармак”, Україна) вводили per os у дозі 10 мкг/кг [1], тіотриазолін - 117 мг/кг внутрішньочеревно [8].

З експерименту тварин виводили шляхом внутрішньочеревного введення великих доз концентрованого тіопенталу натрію. Всі експериментальні дослідження проводили відповідно до принципів біоетики, що викладені у Гельсинській декларації та Законі України "Про захист тварин від жорстокого поводження" (№ 1759-VI від 15.12.2009)

Матеріал для гістологічного дослідження (шматочки яєчок) забирали через 1; 3; 7; 14 і 28 діб після операції. Гістологічні зрізи забарвлювали гематоксиліном і еозином та за Ван Гізон. Визначення маси яєчка проводили за допомогою ваги Т11/500, об'єм визначили за тривимірною фрормулою еліпсоїда $[9,10]$ :

$V=4 / 3 \times(\pi \times a \times b \times c)$

де

a - перша (велика) напіввісь;

b - друга (середня) напіввісь;

c - третя (мала) напіввісь.

При оглядовій мікроскопії вивчали морфологічні особливості будови яєчок, після чого визначили кількість звивистих сім'яних канальців у одному полі зору та наступні морфометричні показники: товщину білкової оболонки, товщину сперматогенного епітелію. Оцінку фрункціональної активності яєчок проводили шляхом вирахування індексу сперматогенезу (IC) [11] :

$\mathrm{IC}=\sum \mathrm{a} / \mathrm{N}$,

де а - кількість шарів виділених у кожному канальці (перший шар - сперматогонії, другий - сперматоцити, третій спрематиди, четвертий - сперматозоїди), а N кількість прорахованих канальців [12].

Оцінку функціонального стану судин проводили шляхом вирахування індексу Вогенворта (IB) $[13,14]$. 
Отриманий цифровий матеріал піддавали статистичній обробці за допомогою Microsoft Exel for Windows 98 із визначенням середніх величин та їх стандартних похибок. Достовірність різниці визначали непараметричним методом за U-критерієм Манна-Уїтні.

РЕЗУЛЬТАТИ ДОСЛІДЖЕНЬ ТА ЇХ ОБГОВОРЕННЯ Після тиреоїдектомії у статевих залозах щурів-самців було виявлено значні розлади органного кровообігу, які на ранніх стадіях проявлялися вираженим венозним і помірним артеріальним повнокров'ям з одночасним розвитком інтерстиційного набряку. В подальшому артеріальний відділ органного кровоносного русла реагував зменшенням своєї пропускної здатності за рахунок звуження просвіту дрібних артерій і артеріол, на тлі яких розвивалися та прогресували дистросрічні зміни як у стромі, так і в паренхімі органа. Трофічні розлади супроводжувалися спустошенням сім'яних канальців унаслідок різкого зменшення у них клітин сперматогенного епітелію, їх фріброзною трансорормацією та наступним розростанням сполучної тканини в інтерстиції.

Виявлені при візуальному дослідженні гістологічні зміни мали своє кількісне підтвердження. При органометрії було встановлено, що через одну добу після тиреоїдектомії достовірно на 19,8 і 34,9 \% збільшувалися маса і об'єм яєчка (табл. 1). У подальшому ці показники набували поступового оборотного розвитку і вже на кінець експерименту (28 доба спостереження) вони достовірно на 24,7 і 46,7 \% були меншими від контрольного рівня.

При морфометричному дослідженні гістологічних зрізів було встановлено також прогресивне зниження рівня усіх морфометричних показників, крім товщини білкової оболонки (табл. 2).
Вже на кінець експерименту кількість звивистих сім'яних канальців у одному полі зору достовірно зменшувалася на 38,2 \%, товщина сперматогенного епітелію - на 23,8 \% й індекс сперматогенезу - на 6,6 \%. Щодо білкової оболонки, то вона на першу добу дещо потоншувалася. У подальшому її товщина поступово наростала і на кінець експерименту достовірно на 22, 7 \% перевищувала висхідний рівень.

Застосування медикаментозної корекції мало позитивний вплив як на стан органного кровообігу, так і відповідно на морфофрункціональний стан яєчок щурів. Причому комбіноване застосування L-тироксину з тіотриазоліном було більш ефективним, ніж монотерапія L-тироксином. Зокрема, що стосується органометрії, то при корекції лише L-тироксином лінійні показники яєчок змінювалися значно меншою мірою, ніж у некоригованих щурів, а при комбінованому застосуванні L-тироксину 3 тіотриазоліном вони практично залишалися на тому ж рівні, що і в контрольних тварин. Лише на першу добу в обох коригованих групах відмічалася незначна тенденція до їх збільшення, що може бути зумовлене застійним повнокров'ям як реакції на операційну травму.

Згідно $з$ цим, маса й об'єм яєчка через 1 добу після тиреоїдектомії у тварин з корекцією лише L-тироксином перевищували контрольні значення на 5,5 і 14,6 \% (будучи водночас на 11,9 і 15,1 \% нижчим від рівня, зареєстрованого у тварин після тиреоїдектомії без корекції).

У щурів із комбінованою корекцією шляхом поєднаного застосування L-тироксину 3 тіотриазоліном така відмінність була наступною: перевищення контрольного рівня за масою сягало 14,8 \% (будучи водночас на 4,1 \%

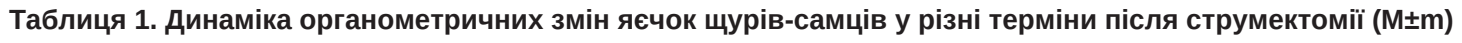

\begin{tabular}{|c|c|c|c|c|c|c|c|}
\hline \multirow{2}{*}{\multicolumn{2}{|c|}{ Показник }} & \multicolumn{6}{|c|}{ Група спостережень } \\
\hline & & контроль & 1 доба & 3 доби & 7 діб & 14 діб & 28 діб \\
\hline \multirow{3}{*}{$\begin{array}{c}\text { Maca } \\
\text { (г) }\end{array}$} & без корекції & $1,82 \pm 0,09$ & $2,18 \pm 0,04^{*}$ & $1,94 \pm 0,04$ & $1,76 \pm 0,04$ & $1,55 \pm 0,05^{*}$ & $1,37 \pm 0,05^{*}$ \\
\hline & корекція L-тироксином & - & $1,92 \pm 0,08$ & $1,89 \pm 0,06$ & $1,81 \pm 0,06$ & $1,67 \pm 0,08$ & $1,53 \pm 0,04$ * \\
\hline & L-тироксином, тіатриазоліном & - & $2,09 \pm 0,07$ & $1,90 \pm 0,06$ & $1,77 \pm 0,06$ & $1,78 \pm 0,07$ & $1,85 \pm 0,06$ \\
\hline \multirow{3}{*}{$\begin{array}{l}\text { Об'єм } \\
\left(\mathrm{CM}^{3}\right)\end{array}$} & без корекції & $1,03 \pm 0,06$ & $1,39 \pm 0,07^{*}$ & $1,26 \pm 0,01^{*}$ & $1,09 \pm 0,04$ & $0,80 \pm 0,04^{*}$ & $0,55 \pm 0,02^{*}$ \\
\hline & корекція L-тироксином & - & $1,18 \pm 0,06$ & $1,05 \pm 0,05$ & $0,99 \pm 0,06$ & $0,94 \pm 0,08$ & $0,85 \pm 0,08$ \\
\hline & L-тироксином, тіатриазоліном & - & $1,18 \pm 0,10$ & $1,12 \pm 0,07$ & $1,02 \pm 0,03$ & $1,00 \pm 0,06$ & $1,04 \pm 0,10$ \\
\hline
\end{tabular}

Примітка. * - p<0,05.

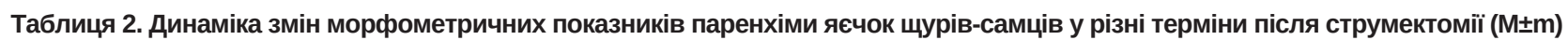

\begin{tabular}{|c|c|c|c|c|c|c|c|}
\hline & \multirow{2}{*}{ Показник } & \multicolumn{6}{|c|}{ Група спостережень } \\
\hline & & контроль & 1 доба & З доби & 7 діб & 14 діб & 28 діб \\
\hline \multirow{3}{*}{$\begin{array}{l}\text { Кількість звивистих } \\
\text { сім'яних канальців } \\
\text { у одному полі зору }\end{array}$} & без корекції & $36,67 \pm 0,84$ & $33,33 \pm 0,61$ & $32,00 \pm 0,68^{*}$ & $29,33 \pm 0,76^{*}$ & $24,67 \pm 0,84^{*}$ & $22,67 \pm 0,80^{*}$ \\
\hline & корекція L-тироксоном & - & $35,67 \pm 0,76$ & $35,00 \pm 0,68$ & $35,00 \pm 0,82$ & $34,17 \pm 0,79$ & $32,67 \pm 0,61^{*}$ \\
\hline & L-тироксином, тіатриазоліном & - & $35,17 \pm 0,60$ & $35,33 \pm 0,76$ & $35,33 \pm 0,80$ & $35,83 \pm 0,75$ & $36,5 \pm 0,56$ \\
\hline \multirow{3}{*}{$\begin{array}{l}\text { Товщина білкової } \\
\text { оболонки, мкм }\end{array}$} & без корекції & $36,69 \pm 2,14$ & $34,05 \pm 2,25$ & $36,13 \pm 2,09$ & $39,24 \pm 2,54$ & $43,71 \pm 2,38$ & $45,04 \pm 2,44^{*}$ \\
\hline & корекція L-тироксином & - & $35,25 \pm 2,01$ & $36,44 \pm 1,85$ & $36,64 \pm 1,91$ & $37,52 \pm 2,14$ & $39,54 \pm 1,81$ \\
\hline & L-тироксином, тіатриазоліном & - & $36,08 \pm 1,92$ & $35,85 \pm 2,03$ & $36,60 \pm 1,96$ & $37,15 \pm 1,95$ & $37,21 \pm 1,86$ \\
\hline \multirow{3}{*}{$\begin{array}{l}\text { Товщина сперма- } \\
\text { тогенного епітелію } \\
\text { (мкм) }\end{array}$} & без корекції & $41,27 \pm 1,63$ & $42,18 \pm 1,84$ & $39,35 \pm 1,39$ & $35,40 \pm 1,51^{*}$ & $33,29 \pm 1,50^{*}$ & $31,46 \pm 1,81^{*}$ \\
\hline & корекція L-тироксином & - & $42,34 \pm 1,21$ & $40,35 \pm 1,27$ & $39,90 \pm 1,54$ & $39,60 \pm 1,43$ & $35,42 \pm 1,13^{*}$ \\
\hline & L-тироксином, тіатриазоліном & - & $43,04 \pm 1,12$ & $40,12 \pm 1,54$ & $40,33 \pm 1,54$ & $40,26 \pm 1,44$ & $40,41 \pm 1,33$ \\
\hline \multirow{3}{*}{$\begin{array}{l}\text { Iндекс спермато- } \\
\text { генезу }\end{array}$} & без корекції & $3,33 \pm 0,03$ & $3,30 \pm 0,03$ & $3,29 \pm 0,03$ & $3,19 \pm 0,03^{*}$ & $3,15 \pm 0,02^{*}$ & $3,11 \pm 0,03^{*}$ \\
\hline & корекція L-тироксином & - & $3,31 \pm 0,03$ & $3,23 \pm 0,03$ & $3,24 \pm 0,02$ & $3,240,03$ & $3,35 \pm 0,04$ \\
\hline & L-тироксином, тіатриазоліном & - & $3,36 \pm 0,04$ & $3,33 \pm 0,04$ & $3,27 \pm 0,02$ & $3,29 \pm 0,04$ & $3,32 \pm 0,04$ \\
\hline
\end{tabular}

Примітка. * - p<0,05. 
нижчим від рівня, зареєстрованого у тварин після тиреоїдектомії без корекції), а перевищення контрольного рівня за об'ємом - 14,6 \% (будучи водночас на 15,1 \% нижчим від рівня, зареєстрованого у тварин після тиреоїдектомії без корекції).

В усі наступні терміни спостереження дані показники поступово поверталися до рівня, що було засріксовано у контрольній групі щурів. Хоча необхідно зауважити, що, якщо при застосуванні L-тироксину в комбінації із тіотриазоліном рівень показників практично повністю відновлювався, то при монотерапії лише L-тироксином зберігалася помітна різниця між експериментальними і контрольними щурами, яка для маси складала 15,9 \% і для об'єму - 17,5\%.

Щодо інших морфометричних показників, то при монотерапії лише L-тироксином кількість звивистих сім'яних канальців у одному полі зору через 1 добу після тиреоїдектомії ставала на 2,7 \% меншою від контрольних цифр, водночас перевищуючи рівень прооперованих тварин без корекції на 7,0 \% (при поєднаному застосуванні L-тироксину з тіотриазоліном така різниця складала 4,1 i 5,5 \%). У подальші терміни при монотерапії лише L-тироксином кількість звивистих сім'яних канальців у одному полі зору все-таки набувала тенденції до зниження, а при поєднаному застосуванні L-тироксину з тіотриазоліном, навпаки, їх кількість дещо наростала. Тому через 28 діб після операції при монотерапії лише L-тироксином кількість звивистих сім'яних канальців у одному полі зору була на була на 10,1 \% меншою від контрольних цифр, водночас перевищуючи рівень прооперованих тварин без корекції на 44,1% (при поєднаному застосуванні L-тироксину з тіотриазоліном така відмінність складала 0,5 і 61,0 \%).

щодо товщини білкової оболонки, то при монотерапії лише L-тироксином через 1 добу після тиреоїдектомії вона зменшувалася на 3,9 \%, порівняно з контрольними тваринами, водночас перевищуючи рівень прооперованих тварин без корекції на 3,5 \% (при поєднаному застосуванні L-тироксину з тіотриазоліном така відмінність складала 1,7 і 6,0 \%). У подальші терміни при монотерапії лише L-тироксином товщина білкової оболонки дещо наростала з частковим перевершенням контрольного рівня, а при поєднаному застосуванні L-тироксину з тіотриазоліном вона практично не відрізнялася від показника інтактних тварин. Тому через 28 діб після операції при монотерапії лише L-тироксином товщина білкової оболонки була на 7,8 \% більшою від контрольних цифрр, водночас не досягаючи рівня прооперованих тварин без корекції на 12,2 \% (при поєднаному застосуванні L-тироксину 3 тіотриазоліном така відмінність складала 1,4 і 17,4 \%).

Дещо іншого характеру набували кількісні зміни товщини сперматогенного епітелію. Якщо через 1 добу після операції його товщина, порівняно з контрольними тваринами, збільшувалася майже однаково як у прооперованих тварин без корекції, так і при застосуванні різних методів корекції (на 2,2-4,3 \%), то у подальшому вона поступово зменшувалася. Але, якщо у щурів із застосуванням лише монотерапії L-тироксином через 28 діб експерименту товщина сперматогенного епітелію ставала меншою від контрольного рівня (на 14,2 \%), одночасно перевищуючи рівень прооперованих тварин без корекції (на 12,6 \%), то у тварин із поєднаним застосуванням L-тироксину 3 тіотриазоліном даний показник практично виходив на рівень інтактних тварин.
При цьому, якщо індекс сперматогенезу після тиреоїдектомії без застосування корекції поступово знижувався і до кінця експерименту достовірно на 6,6 \% був нижчим від контрольних величин, то в обох коригованих групах даний показник суттєво не мінявся протягом усього експерименту. Незначна тенденція до зниження спостерігалася лише у щурів із монотерапією L-тироксином посттиреоїдектомічного гіпотиреозу.

Щодо ремоделювання органного кровоносного судинного русла яєчок щурів після тиреоїдектомії, то воно зазнавало суттєвої перебудови, причому характер зміни його кількісних показників також залежав від виду коригуючого впливу. Більш есрективно відновлення структурної організації стінок артерій і їх морфометричних характеристик відбувалося при поєднаному застосуванні L-тироксину і тіотриазоліну порівняно з монотерапією лише L-тироксином. Причому, якщо через першу добу після операції морфоорункціональні реакції артерій суттєво не відрізнялися і принципово не залежали від типу коригуючого впливу чи його відсутності, то починаючи 3 3-ї і до 7-ї доби експерименту, в реакціях судин вже відмічалися деякі відмінності (табл. 3).

Так, якщо у тварин без корекції чи з корекцією лише L-тироксином при певній стабільності стану середніх інтрамуральних артерій білкової оболонки відбувалося подальше звуження просвіту дрібних інтрамуральних артерій (причому дещо інтенсивніше у щурів без корекції), то у тварин з комбінованою корекцією L-тироксином і тіотриазоліном відмічалося часткове відновлення пропускної здатності дрібних інтрамуральних артерій, що підтверджувалося відповідним зниженням у них рівня індексу Вогенворта (табл. 3).

Починаючи з 7-ї і до 28-ї доби спостереження, у тварин без корекції відбувалося подальше розширення просвіту артерій білкової оболонки із одночасним звуженням просвіту вже не тільки дрібних, але й інтрамуральних артерій середнього калібру, що підтверджувалося відповідною динамікою індексу Вогенворта.

У тварин із корекцією лише L-тироксином показники морфоорункціонального стану артерій на завершальній стадії експерименту за своїм значенням наближалися до контрольних величин, однак у них ще зберігалася тенденція до розширення просвіту артерій білкової оболонки з одночасною тенденцією до звуження просвіту дрібних і середніх інтрамуральних артерій.

Більш ефрективним було застосування комбінованої корекції L-тироксином у поєднанні з тіотриазоліном. Через 28 діб експерименту індекс Вогенворта у даної групи щурів був найбільш наближеним до контрольного рівня. Так, якщо різниця між контрольними показниками і показниками тварин без корекції за індексом Вогенворта в артеріях білкової оболонки, інтрамуральних артеріях середнього і дрібного калібрів складала (-)10,0 \%; (+)19,2 \% і (+)17,9 \%, то при монотерапії L-тироксином вона була наступною: (-)5,1 \%; (+)4,5; (+)5,2 \%, а при комбінованій корекції L-тироксином у поєднанні 3 тіотриазоліном (+)1,8 \%; (+)0,1% і (+)0,7 \% відповідно.

Таким чином, підсумовуючи, можна сказати, що виявлені структурні зміни в яєчках щурів після тиреоїдектомії $€$ наслідком як безпосереднього впливу гіпотиреозу на стан їх структурних компонентів, так і опосередкованого через порушення органного кровотоку. Застосування монотерапії L-тироксином у післяопераційному періоді лише частково попереджає розвиток виявлених мор- 
Таблиця 3. Динаміка змін індексу Вогенворта галужень яєчкових артерій щурів-самців у різні терміни після струмектомії

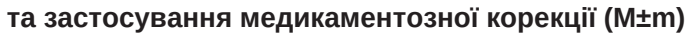

\begin{tabular}{|c|c|c|c|c|}
\hline \multirow{3}{*}{$\begin{array}{c}\text { Тривалість спо- } \\
\text { стереження }\end{array}$} & \multirow{3}{*}{ Вид втручання } & \multicolumn{3}{|c|}{ Порядок галуження судин і їх параметри } \\
\hline & & $\begin{array}{c}\text { артерії білкової оболонки } \\
\text { (136-180 мкм) }\end{array}$ & $\begin{array}{c}\text { інтрамуральні артерії } \\
\text { середнього калібру } \\
\text { (51-135 мкм) }\end{array}$ & $\begin{array}{c}\text { дрібні інтрамуральні } \\
\text { артерії } \\
\text { (26-50 мкм) }\end{array}$ \\
\hline & & IB & IB & IB \\
\hline & Контроль & $188,61 \pm 2,52$ & $180,76 \pm 3,21$ & $358,28 \pm 8,13$ \\
\hline \multirow{3}{*}{1 доба } & без корекції & $174,68 \pm 2,76^{\star}$ & $172,30 \pm 2,64$ & $388,62 \pm 8,14$ \\
\hline & корекція L-тироксином & $172,35 \pm 2,10^{*}$ & $167,41 \pm 2,93^{\star}$ & $376,81 \pm 7,77$ \\
\hline & L-тироксином, тіатриазоліном & $176,87 \pm 2,92^{\star}$ & $171,73 \pm 3,01^{*}$ & $380.06 \pm 6,89$ \\
\hline \multirow{3}{*}{3 доби } & без корекції & $178,39 \pm 2,42^{*}$ & $178,62 \pm 3,97$ & $394,41 \pm 6,91^{\star}$ \\
\hline & корекція L-тироксином & $179,03 \pm 2,49$ & $174,41 \pm 4,05^{\star}$ & $379,32 \pm 6,98$ \\
\hline & L-тироксином, тіатриазоліном & $185,66 \pm 2,68$ & $175,55 \pm 3,60 *$ & $374,78 \pm 8,21$ \\
\hline \multirow{3}{*}{7 діб } & без корекції & $178,49 \pm 2,23^{*}$ & $190,97 \pm 3,30^{\star}$ & $403,08 \pm 9,54^{\star}$ \\
\hline & корекція L-тироксином & $181,04 \pm 2,80$ & $178,83 \pm 3,48$ & $373,92 \pm 7,98$ \\
\hline & L-тироксином, тіатриазоліном & $182,63 \pm 3,09$ & $177,81 \pm 3,73$ & $368,85 \pm 7,92$ \\
\hline \multirow{3}{*}{14 діб } & без корекції & $178,97 \pm 2,33^{*}$ & $198,79 \pm 4,37^{\star}$ & $406,08 \pm 9,10^{*}$ \\
\hline & корекція L-тироксином & $173,20 \pm 3,04$ & $183,56 \pm 2,50 *$ & $376,75 \pm 9,16$ \\
\hline & L-тироксином, тіатриазоліном & $183,63 \pm 2,64^{*}$ & $176,42 \pm 2,82$ & $365,29 \pm 6,35$ \\
\hline \multirow{3}{*}{28 діб } & без корекції & $169,82 \pm 2,17^{*}$ & $215,44 \pm 3,32^{*}$ & $422,30 \pm 10,61^{*}$ \\
\hline & корекція L-тироксином & $178,64 \pm 3,80$ & $188,26 \pm 2,65^{\star}$ & $374,39 \pm 9,04^{\star}$ \\
\hline & L-тироксином, тіатриазоліном & $190,24 \pm 3,92^{*}$ & $180,65 \pm 1,80$ & $361,85 \pm 8,69 *$ \\
\hline
\end{tabular}

Примітка. * $-p<0,05$.

фофрункціональних змін. Більш ефективним є комплексне поєднане застосування L-тироксину з тіотриазоліном.

ВИснОВкИ 1. У яєчках щурів після тиреоїдектомії розвиваються трофрічні розлади, які призводять до спустошення сім'яних канальців унаслідок різкого зменшення у них клітин сперматогенного епітелію, їх фріброзної трансорормації з наступним розростанням сполучної тканини в інтерстиції.

Виявлені структурні зміни є наслідком як безпосереднього впливу гіпотиреозу на стан структурних компонен- тів яєчок щурів, так і опосередкованого через порушення органного кровотоку.

Монотерапія гіпотиреозу L-тироксином у післяопераційному періоді лише частково попереджає розвиток виявлених морфоорункціональних змін, більш ефективним $€$ поєднане застосування L-тироксину з тіотриазоліном.

Перспективи подальших наукових досліджень полягають у подальших наукових дослідженнях, що можуть стати підґрунтям для розробки нових ефективних методів корекції гіпотиреозу та їх морфрофункціональної оцінки.
СПИСОК ЛІТЕРАТУРИ

1. Кузьменко Ю. Ю. Вплив медикаментозної корекції на ультраструктуру нефрона нирки щурів з гіпотиреозом / Ю. Ю. Кузьменко // Здобутки клінічної і експериментальної медицини. 2010. - № 1. - С. 83-86.

2. Кузьменко Ю. Ю. Імуногістохімічне дослідження нирки щурів при вродженому і набутому гіпотиреозі та за умов замісної гормонотерапії / Ю. Ю. Кузьменко, Л. О. Стеченко // Світ медицини та біології. - 2016. - № 3 (57). - С. 118-122.

3. Ультраструктурні прояви неповноцінності жовтого тіла при експериментальному гіпотиреозі у невагітних щурів / В. Р. Кузян, Т. П. Куфртирева, Л. О. Стеченко [та ін.] // Морфрологічний вісник. - 2007. - № 3. - С. 227-232.

4. Сердце при гипотиреозе (экспериментальное исследование) / Л. А. Стеченко, В. А. Петренко, Т. П. Кусртырева [и др.]. - К., 2008. - C. 196.

5. Фадеев В. В. Актуальные вопросы заместительной терапии гипотиреоза / В. В. Фадеев, Т. Б. Моргунова // Фарматека. -2007. - №11. - C. 1-5.

6. Тронько М. Д. Пріоритетні проблеми клінічної ендокринології в Україні на сучасному етапі / М. Д. Тронько // Здоров'я України. - 2012. - № 2-3(18-19). - С. 10-11.

7. Каюмов У. К. Новые перспективы применения тиотриазолина в общеврачебной практике / У. К. Каюмов // Запорожский медицинский журнал. - 2010. - Т. 12, № 5. - С. 34-36.

8. Волошина І. С. Ефректи інгаляційного впливу епіхлоргідріну на сім'яники статевонезрілих щурів / I. С. Волошина // Український морфологічний альманах. - 2011. - Т. 9, № 3. - С. 62-64.

9. Бобылев Д. К. Эллипсоид/Д. К. Бобылев//Энциклопедический словарь Брокгаузена и Ефрона : СПб., 1890-1907. - Т. 86.

10. Гриценко С. І. Спосіб вимірювання об'єму біологічних об'єктів / С. І. Гриценко, О.О.Вільцанюк // Вісник морфології. - 2000. - №2. - С. 333-334.

11. Морфоорункциональная характеристика семенников крыс Вистар при воздействии липополисахарида в условиях гиперандрогенемии / С. Г. Васильева, В. А. Мхитаров, А. М. Косырева, О.В.Макарова // Российский медико-биологический вестник имени академика И. П. Павлова. - 2011. - № 2. - С. 35-40.

12. Дуденкова Н. А. Изменения функционального состояния и продуктивности семенных желез белых крыс при воздействии ацетата свинца/Н.А.Дуденкова, О. С. Шубина// Фундаментальные исследования. - 2013. - Т. 8, №10. - С. 1253-1259.

13. Саливанов А. А. Морфологические изменения в стенке аорты после кровопотери (экспериментальное исследование) / А. А. Саливанов, В. Т. Долгих // Общая реаниматология. -2014. - T. 10, № 4. - С. 37-43.

14. Изменение активности нейрокининовой системы в слизистой оболочке верхних дыхательных путей крыс при моделировании хронического табакокурения / Ю. Б. Лепейко, В. А. Невзорова, Е. А. Гилифанов [и др.] // Сибирский научный медицинский журнал. - 2015. - Т. 35, № 1. - С. 19-27.

Отримано 05.01.18 


\section{HYPOTHYROIDISM DRUG CORRECTION INFLUENCE ON TESTICLE STRUCTURE AFTER THYROIDECTOMY}

Summary. The question of finding effective approaches to the medical correction of hypothyroidism and their morphofunctional justification continues to be one of the current issues of modern medical science.

The aim of the study - to give a comparative morphofunctional characteristic of the effectiveness of monotherapy with L-thyroxin and its combination with thiotriazoline for the correction of post-thyroidectomy hypothyroidism.

Materials and Methods. Experiments were carried out on mature white laboratory male rats. The mass of testicles has been established, with father observational microscopy studied of the morphological features of their structure, determined the number of convoluted seminal canals in one field of vision and the following morphometric parameters: the thickness of the protein shell, the thickness of the spermatogenic epithelium. The functional activity of the testicles was carried out by deducting the index of spermatogenesis, functional state of the vessels was carried out according to the the Wagovert index value.

Results and Discussion. After thyroidectomy in the gonads of male rats, significant organ-related circulatory disorders were detected, which in the early stages were manifested by pronounced venous and moderate arterial hypertension with the simultaneous development of interstitial edema. Subsequently, the arteries of the organ reacted with a decrease of their throughput due to the narrowing of the lumen of small arteries and arterioles, which caused dystrophic changes in both the stroma and parenchyma of the organ. Trophic disorders were accompanied by the desertification of seminal tubules as a result of a quick decrease in spermatogenic epithelium cells quantity, their fibrous transformation and subsequent growth of the connective tissue in the interstitial one. The revealed structural changes are a consequence of both the direct influence of hypothyroidism on the state of their structural components, and indirectly due to violation of the organ blood flow. The use of monotherapy with L-thyroxine in the postoperative period only partly prevents the development of detected morphofunctional changes.

Conclusions. More effective is the combined use of L-thyroxin with thiotriazolinum.

Key words: hypothyroidism; spermatogenesis; blood circulation; dystrophy.

С๐. П. Илькив, И. Е. Герасимюк, З. М. Небесна ГВУЗ “Тернопольский государственный медицинский университет имени И. Я. Горбачевского"

\section{ВЛИЯНИЕ МЕДИКАМЕНТОЗНОЙ КОРРЕКЦИИ ГИПОТИРЕОЗА НА СОСТОЯНИЕ СТРУКТУРНОЙ ОРГАНИЗАЦИИ ЯИЧЕК КРЫС ПОСЛЕ ТИРЕОИДЭКТОМИИ}

Резюме. Вопрос поиска эффрективных подходов к медикаментозной коррекции гипотиреоза и их морфофункциональное обоснование продолжает оставаться одним из актуальных вопросов современной медицинской науки.

Цель исследования - дать сравнительную морфофункциональную характеристику эффективности применения монотерапии L-тироксином и его комбинации с тиотриазолином для коррекции посттиреоидектомического гипотиреоза.

Материалы и методы. Эксперименты проведены на половозрелых белых лабораторных крысах-самцах. Определяли массу яичек, при обзорной микроскопии изучали морфологические особенности их строения, определяли количество извитых семенных канальцев в одном поле зрения и следующие морфометрические показатели: толщину белковой оболочки, толщину сперматогенного эпителия. Оценку функциональной активности яичек проводили путем вычисления индекса сперматогенеза, оценку функционального состояния сосудов проводили за величиной индекса Вогенворта.

Результаты исследований и их обсуждение. После тиреоидэктомии в половых железах крыс-самцов были выявлены значительные нарушения органного кровообращения, которые на ранних стадиях проявлялись выраженным венозным и умеренным артериальным полнокровием с одновременным развитием интерстициального отека. В дальнейшем артериальный отдел органного кровеносного русла реагировал уменьшением своей пропускной способности за счет сужения просвета мелких артерий и артериол, на фоне которых развивались и прогрессировали дистрофические изменения как в строме, так и в паренхиме органа. Трофические расстройства сопровождались опустошением семенных канальцев вследствие резкого уменьшения в них клеток сперматогенного эпителия, их фиброзной трансформацией и последующим разрастанием соединительной ткани в интерстиции. Выявленные структурные изменения являются следствием как непосредственного влияния гипотиреоза на состояние их структурных компонентов, так и опосредованного вследствие нарушения органного кровотока. Применение монотерапии L-тироксином в послеоперационном периоде только частично предупреждает развитие выявленных морфоорункциональных изменений.

Выводы. Среди исследуемых препаратов более эффрективным в условиях эксперимента является комплексное сочетанное применение L-тироксина с тиотриазолином.

Ключевые слова: гипотиреоз; сперматогенез; кровообращение; дистрофия. 